\title{
Особенности формирования городского расселения в Туве в советский период
}

\author{
Марианна М.-Б. Харунова
}

Тувинский институт комплексного освоения природных ресурсов СО РАН, Российская Федерация, Рамиль Ш. Харунов

Нацииональный музей им. Алдан-Маадыр Республики Тыва, Российская Федерация
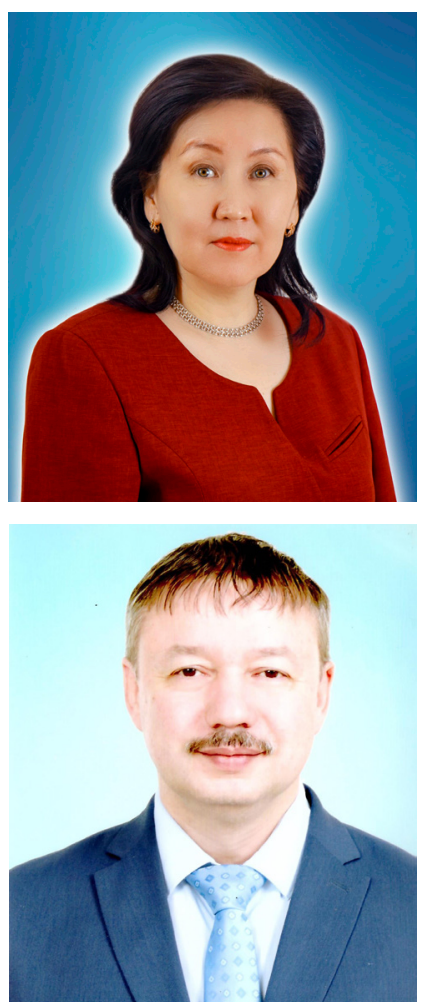

В статье рассмотрены некоторые аспекты из истории появления городских поселений Тувы - городов и поселков городского типа во второй половине XX века. Выделены экономические факторы (развитие промышленности, производства), а также некоторые социальные условия (рост жилищного фонда, более высокая заработная плата рабочих городских профессий). Основными источниками формирования и увеличения городского населения названы: придание статуса городских поселений части населенных пунктов, механический прирост жителей городов и трудовая миграция населения из сел Тувы и других районов страны.

На статистических данных показана динамика численности горожан с 1959 по 1989 г2., их удельный вес в общей статистике населения Тувы. К 1989 г. удельный вес горожан в республике составил 47,1\%. Разница в численности мужчин и женщин среди городского населения в возрасте моложе трудоспособного и в трудоспособном возрасте была незначительной. Практически выровнялось количество городских и сельских семей. Быстрыми темпами росло население столицы г. Кызыла, которое в 1989 г. составляло 27\% от общего числа жителей республики.

Неравномерность городского расселения населения в Туве, которая сложилась еще в середине ХХ века, продолжает определять современную структуру расселения и основную проблему - продолжающийся переезд сельских жителей в г. Кызыл и на его окраины.

Ключевые слова: Тува; история Тувы; население; урбанизация; социально-экономическое развитие; городское расселение

Для цитирования:

Харунова М. М.-Б., Харунов Р. Ш. Особенности формирования городского расселения в Туве в советский период // Новые исследования Тувы. 2021, № 3. С. 137-147. DOI: https://www.doi.org/10.25178/nit.2021.3.11

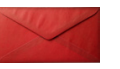

Харунова Марианна Монге-Байыровна - кандидат исторических наук, ведущий научный сотрудник лаборатории математического моделирования Тувинского института комплексного освоения природных ресурсов СО РАН. Адрес: 667007, Россия, г. Кызыл, ул. Интернациональная, д. 117А. Тел.: +7 (394-22) 6-62-18. Эл. адрес: ondar18@mail.ru

Харунов Рамиль Шатмуратович - кандидат исторических наук, заведующий филиалом Алдын-Дошка Национального музея им. Алдан-Маадыр Республики Тыва. Адрес: 667000, Россия, г. Кызыл, ул. Титова, д. 30. Тел.: +7 (394-22) 2-28-04. Эл. адрес: ramar33@mail.ru

KHARUNOVA, Marianna Monge-Bairovna, Candidate of History, Leading Research Fellow, Laboratory of Mathematical Modeling, Tuvinian Institute for Exploration of Natural Resources, Siberian Branch, Russian Academy of Sciences. Postal address: 117A Internatsionalnaya St., 667010 Kyzyl, Russian Federation. Tel.: +7 (394-22) 2-28-04. E-mail: Ondar18@mail.ru ORCID ID: 0000-0002-9011-2262

KHARUNOV, Ramil Shatmuratovich, Candidate of History, Head, Aldyn-Doshka branch, Aldan-Maadyr National Museum of the Republic of Tuva. Postal address: 30 Titov St., 667000 Kyzyl, Russian Federation. Tel.:+7 (394-22) 2-28-04. E-mail: ramar33@mail. $\mathrm{ru}$ ORCID ID: 0000-0001-7940-5972 


\title{
Features of urban settlement in Tuva in the Soviet period
}

\author{
Marianna M.-B. Kharunova \\ Tuvan Institute for Exploration of Natural Resources, Siberian Branch, \\ Russian Academy of Sciences, Russian Federation, \\ Ramil Sh. Kharunov \\ Aldan Maadyr National Museum of the Republic of Tuva, Russian Federation
}

\begin{abstract}
The article examines various aspects of history of the rise of urban settlements in Tuva - towns and urban-type localities - in the latter half of the 20th century. The author focus primarily on contributing factors in economy (such as the development of industrial manufacturing) and in social life (e.g., improved housing and higher salaries for workers in urban settlements). Among the factors which contributed to the increase in urban population were the promotion of some existing settlements to urban status, incremental growth and labour-related migration from rural Tuva and other regions of Russia.

Statistical data included into the article shows the numerical strength of urban population from 1959 to 1989, including their share in the demographic of Tuva. By 1989, this share has reached 47.1\%, with the difference between male and female populations of working age and beyond it quite negligible. The number of urban and rural households turned almost equal, and the population growth in the capital city of Kyzyl was high (27\% of Tuva's total in 1989).

Since mid-20th century, urban settling in Tuva has been unbalanced, which continues to be a major factor in the structure of urban population and its biggest problem - the ongoing migration of rural population to Kyzyl and its suburbs.
\end{abstract}

Keywords: Tuva; history of Tuva; population; urbanization; socioeconomic development; urban settling

For citation:

Kharunova M. M.-B. and Kharunov R. Sh. Osobennosti formirovaniia gorodskogo rasseleniia v Tuve v sovetskii period [Features of urban settlement in Tuva in the Soviet period]. New Research of Tuva, 2021, no. 3, pp. 137-147. (In Russ.). DOI: https://www.doi.org/10.25178/nit.2021.3.11

\section{Введение}

В современной Туве, как и в России в целом, наблюдается неравномерность в территориальном расселении населения. Социально-экономические последствия кризиса 1990-х годов способствовали формированию новых реалий. В поисках перспектив и новых возможностей, в результате кризиса сельских территорий население стало менять свои жизненные стратегии в поисках перспектив и новых возможностей, ориентируясь на большие города. В пределах Республики Тыва это прежде всего г. Кызыл. Увеличение численности населения столицы, изменение структуры городского населения, разрастающаяся пригородная зона, развитие инфраструктуры, проблемы благоустройства города эти и другие факторы усугубляются в целом неравномерным размещением населения на территории республики.

Необходимо отметить, что данная тенденция отмечалась еще в советское время, когда районы с высокой концентрацией природных ресурсов, прежде всего минерального сырья, намеченных для хозяйственного освоения, располагали наименьшим трудовым потенциалом (Очерки социального ..., 1983: 62).

Расселение - это процесс территориального распределения населения за счет развития старых и образования новых поселений. Оно формируется под влиянием объективных факторов: социальноэкономических, географических, исторических. Неравномерность размещения населения в Туве обусловлена наследием прошлого и является проблемой, которая требует отдельного внимания при стратегическом планировании социально-экономического развития республики. В связи с чем, на 
наш взгляд, является актуальным изучение особенностей территориального расселения, особенно городского населения, основные принципы которого формировались в советское время.

Особенности городского расселения в Туве не являлись предметом специального изучения. В данной работе мы на основе имеющихся научных разработок, отчетов Тувинского республиканского управления статистики с 1949 по 1989 гг., хранящихся в фондах Национального архива Республики Тыва, проанализируем и обобщим особенности формирования городского расселения в республике распределение жителей по городским поселениям: городам и поселкам городского типа в советский период.

Нашей источниковой базой стали труды, в рамках которых рассматривались проблемы формирования городского населения, такие как «Экономика Тувинской АССР» (Экономика Тувинской ..., 1973), «Городское население Тувинской АССР» (Городское население ..., 1981), «Очерки социального развития Тувинской АССР» (Очерки социального ... , 1983), «История Тувы» (История Тувы, 2016); авторские публикации, посвященные социально-демографическим проблемам (Гребнев, 1968; Сердобов, 1977; Бегзи, 1975, 2017; Анайбан, 2011) и др. Данные работы в обозначенном предметом поле приводят объективные статистические материалы по развитию трудовых ресурсов, демографических характеристик, социально-профессиональной мобильности, а также на основе анализа субъективных характеристик (общественное мнение, ценностные ориентации, жизненные планы) рассматривают проблемы урбанизации, социальной адаптации населения Тувы в советский период к новым видам труда и городской культуры. Расселение в основном рассматривалось в аспекте планового совмещения трудовых ресурсов и производства.

Трансформация городского расселения в национальных республиках Южной Сибири - на Алтае, Туве, Хакасии в середине XX - начале XXI в. рассмотрена в работе Е. Е. Тиниковой (Тиникова, 2018), которая пришла к выводу о том, что существующие классификации уровня урбанизационного развития регионов России не учитывают в полном объеме специфику национальных субъектов страны и не отражают реальную картину их городского развития. Она также предложила периодизацию развития урбанизационных процессов в южно-сибирских республиках на основе динамики территориального размещения городского населения.

А. Д. Бегзи, исследуя процессы урбанизации в Туве, начиная с 1914 г. до современности, отметил их взаимосвязь с развитием экономики и реализацией положений Стратегии социально-экономического развития на период до 2030 г. Дальнейшее развитие городов Тувы, по мнению автора, будет зависеть от инвестиций не сырьевого характера, включенных в Стратегию, а также от позиции и поддержки федеральных органов власти (Бегзи, 2019).

\section{Экономические факторы городского расселения в Туве}

До вхождения Тувинской Народной Республики в состав Советского Союза в Туве был один город столица Кызыл. Во второй половине ХХ века к городским поселениям уже относились пять городов: Кызыл (год основания - 1914 г.), Чадан (1883 г.), Туран (1885 г.), Шагонар (1888 г.), Ак-Довурак (1964 г.) и три поселка городского типа - Хову-Аксы (1953 г.), Кызыл-Мажалык (1959 г.), Каа-Хем (1978 г.).

Чадан, Туран и Шагонар получили статус городов 8 мая 1945 г. в соответствии с решением Исполнительного комитета Областного Совета депутатов трудящихся Тувинской автономной области об административно-территориальном составе ТАО (На перекрестке времени ..., 2014: 377).

Ак-Довурак был основан на месте строительства комбината «Тувасбест». Хову-Аксы («Тувакобальт»), Кызыл-Мажалык (промкомбинат), Каа-Хем (Кызылская ТЭЦ) являлись поселками городского типа, выросшими на месте строительства промышленных объектов. Очевидно, что рост количества городских поселений в Туве, как и в целом по СССР в середине XX века, был обусловлен их экономическими функциями в результате развития промышленности, транспорта, энергетики и т. д. (Городское население ..., 1981: 20-21).

А. Д. Бегзи при рассмотрении типов городских поселений предполагал, что можно объединить в одну группу Чадан, Шагонар, Туран и рабочий поселок Кызыл-Мажалык, которые в основном функционировали как административные центры районов. Кроме Чадана промышленность в них была развита слабо (Бегзи, 1975: 64). К такому же выводу пришла Е. Е. Тиникова. По структурно-функциональной типологии городов Южной Сибири Чадан,Шагонар, Туран относятся к 3-му типу городских поселений: «Центры административных районов - монопрофильные города с административнохозяйственными функциями» (Тиникова, 2018: 245). 
Кызыл, наряду с Абаканом и Горно-Алтайском, относится к 1-му типу: «Республиканские столицы центры с многопрофильной специализацией экономики» (там же: 245). В 1958 г. доля промышленных предприятий Кызыла в областном объеме промышленной продукции составляла около 90\%. В 1950-1960-х гг. в Кызыле были введены хлебозавод и молокозавод, пивоваренный завод, мельница (Бегзи, 2019: 53).

Открытие новых промышленных предприятий в Ак-Довураке, Хову-Аксы создало значительное количество рабочих мест. В 1945 г. в промышленности было занято около 900 чел., в 1950 г. - более 2,6 тыс., за 1950-е годы численность работников промышленности возросла в 1,8 раза и достигла 4,8 тыс. чел. Создание новых, преимущественно «городских» рабочих мест способствовало ускорению процессов урбанизации (История Тувы, 2016: 72).

В 1980-е годы открылись новые предприятия легкой промышленности: филиал Кызылской швейной фабрики в пос. Хову-Аксы, Ак-Довуракская швейно-трикотажная фабрика. Начали производственную деятельность две мебельные фабрики, предприятие народно-художественных промыслов в г. Кызыле, в районных центрах работали промышленные комбинаты и комбинаты бытового обслуживания, выпускавшие одежду и обувь (Бегзи, 2017: 97).

Как пишет А. Д. Бегзи, благодаря значительным государственным инвестициям темпы промышленного роста в Туве значительно опережали средние показатели по стране. Общий объем промышленного производства в целом за советский период возрос в 87,8 раза, а в отдельных отраслях энергетика, топливная, производство стройматериалов, - темпы были значительно выше (там же: 97).

Бурный рост производственного потенциала, коренные сдвиги в структуре экономики Тувинской АССР способствовали увеличению численности и повышению удельного веса городского населения и изменениям в системе городского расселения.

Рассмотрим, как происходил рост численности городского населения в советский период (таб. 1).

Таблица 1. Численность городского населения в Туве (1959-1989 г2.) ${ }^{1}$

Table 1. Urban population in Tuva, 1959-1989.

\begin{tabular}{|c|l|c|c|c|c|}
\hline \multirow{2}{*}{$N$ o } & \multicolumn{1}{|c|}{ Городское поселение } & 1959 & 1970 & 1979 & 1989 \\
\hline 1 & г. Кызыл & 34462 & 51683 & 66027 & 84641 \\
\hline 2 & г. Ак-Довурак & - & 9613 & 13216 & 15191 \\
\hline 3 & г. Туран & 3951 & 4539 & 5139 & 5976 \\
\hline 4 & г. Чадан & 4709 & 7589 & 8985 & 10775 \\
\hline 5 & г. Шагонар & 4155 & 4512 & 5455 & 10084 \\
\hline 6 & пгт Каа-Хем & - & - & 4047 & 7297 \\
\hline 7 & пгт Кызыл-Мажалык & 2900 & 4423 & 4983 & 5754 \\
\hline 8 & пгт Хову-Аксы & 50177 & 8632 & 5413 & 5925 \\
\hline \multicolumn{2}{r|}{ Итого } & & 113265 & 145643 \\
\hline
\end{tabular}

Данные таблицы свидетельствуют о значительном росте городского населения за 30 лет - на 95446 чел. Стоит отметить, что на 1 января 1944 г. население республики всего составляло 95025 чел. (Харунова, 2010: 160). С 1959 по 1970 гг. жителей городов стало на 36814 чел. больше, с 1970 по 1979 гг. - на 26274 чел., а с 1979 по 1989 гг. - на 32378 чел. Мы видим, что темпы прироста городского населения с 1959 по 1989 гг. были стабильно высокими, что отражалось в целом на структуре населения республики.

При этом территориальное расселение городского населения было неравномерным. Особенно высокий прирост численности горожан произошел в г. Кызыле. За рассматриваемый период население столицы увеличилось на 50179 чел. Доля кызылчан среди городского населения республики в 1959 г. составляла 68\%, в 1989 г. - 58\%, то есть более половины всех городских жителей. В общем числе всех жителей Тувы в 1959 г. жители столицы составляли 20\%, в 1989 г. - 27\%, в 2002 г. - 30\%, в 2010 г. 36\%. Таким образом, мы видим, что уже к концу советского периода доля жителей г. Кызыла составляла почти треть населения республики, сохраняя тенденцию к увеличению.

Динамика общей численности городского и сельского населения в процентах ко всему населению республики представлена в таблище 2.

${ }^{1}$ Таблица составлена по материалам Тувинского республиканского управления статистики (НА РТ, ф. 263. оп. 1 , д. 1, лл. 1-3; ф. 263, оп. 1, д. 4742, лл. 6, 9, 10, 11, 15, 18, 21, 24). 
Таблица 2. Доля городского и сельского населения в Туве (1959-1989 г2.) ${ }^{1}$

Table 2. The share of urban v. rural population in Tuva, 1959-1989.

\begin{tabular}{|c|c|c|}
\hline \multirow{2}{*}{ Годы } & \multicolumn{2}{|c|}{ В процентах ко всему населению республики } \\
\cline { 2 - 3 } & Городское население & Сельское население \\
\hline 1959 & 29 & 71 \\
\hline 1979 & 43 & 57 \\
\hline 1989 & 47 & 53 \\
\hline
\end{tabular}

Данные таблицы показывают неуклонный рост численности городского населения в Туве. К 1989 г. удельный вес горожан в республике составил $47 \%$.

Исследователи справедливо отмечают, что происходившие изменения в соотношении сельского и городского населения вызваны преобразованием в 1945 г. районных центров - Турана, Шагонара и Чадана в города (Гребнев, 1968: 62).

Большую роль играл и естественный прирост жителей городов, который в Туве был значительно выше, чем в других регионах: в 1965 г. общий коэффициент рождаемости городского населения составил: в РСФСР - 14,4\%, в Восточной Сибири - 16,9\%, Тувинской АССР - 21,3 \%; в 1970 г. соответственно 14,7; 17,3 и 21,7\%. Коэффициент естественного прироста в 1970 г. составил для РСФСР $6,8 \%$, Восточной Сибири - 10,1\%, Тувинской АССР - 13,5\% (Городское население ..., 1981: 24-25). Средний возраст жителей городов в Туве в 1989 г. составлял 28,2 лет (НА РТ, ф. 263, оп. 1, д. 1, л. 59). Соответственно возрастная структура городского населения выглядела следующим образом: чуть более трети были в возрасте моложе трудоспособного, около 60\% - в трудоспособном возрасте, 9\% - старше трудоспособного возраста (диаграмма 1).

К 1989 г. разница в численности мужчин и женщин среди городского населения в возрасте моложе трудоспособного и в трудоспособном возрасте была незначительной. А в категории людей старше трудоспособного возраста женщин насчитывалось на 5990 чел. больше, чем мужчин, что свидетельствует о большей продолжительности жизни женщин (таблица 3).

Помимо естественного прироста еще одним существенным источником увеличения количества городского населения являлась миграция. Города привлекали население более высоким уровнем жизни, более широкими возможностями трудоустройства, получением образования, культурным досугом и т. д. «...По данным 1975 г., размер среднемесячной заработной платы рабочих и служащих в отраслях, характерных для городов, составлял в промышленности 186 руб., строительстве - 182 руб., на транспорте - 188 руб., тогда как в сельском и лесном хозяйстве - лишь 125 руб.» (Городское население ..., 1981: 24-25).

Высокими темпами велось жилищное строительство. Жилищ-

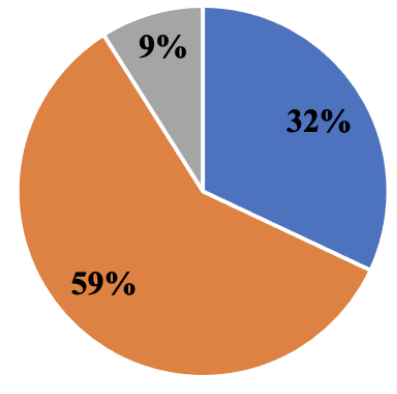

- в возрасте моложе трудоспособного

в трудоспособном возрасте

- в возрасте старше трудоспособного

Диаграмма 1. Распределение городского населения Тувинской АССР по возрасту в 1989 г.

Diagram 1. The age distribution of the urban population of Tuvan ASSR, 1989. ный фонд городов и поселков городского типа с 1960 по 1983 гг.

вырос с 422 тыс. кв. м до 1400 тыс. кв. м в год - то есть более чем в 3 раза². По республике ввод жилья с 1 тыс. кв. м в 1945 г. возрос до 150,8 тыс. кв. м в 1990 г. Всего за это время введено более 3 млн кв. м общей площади жилья. В 1970-1980-е гг. государственные капитальные вложения в жилищное строительство в расчете на 10 тыс. жителей в Туве в полтора-два раза превышали уровень РСФСР. Городской жилищный фонд к концу советского периода превысил 3,6 млн кв. м. (Бегзи, 2017: 100).

${ }^{1}$ Составлено на основе данных источников: Уровень образования, национальный состав, возрастная структура и размещение населения СССР по республикам, краям и областям. По данным Всесоюзной переписи населения 1959 г. М. Госстатиздат. 1960. С. 27; Перепись населения 1979 г. [Электронный ресурс] // Демоскоп. http://www.demoscope.ru/weekly/ssp/rus79_reg1.php (дата обращения: 12.06.2021); Болдырев В. А. Население СССР по данным Всесоюзной переписи населения 1989 г. М. : Изд-во Финансы и статистика, 1990. С. 13.

${ }^{2}$ Советская Тува в цифрах (1984): статистический сборник. Кызыл : Тувинское книжное издательство. С. 117. 
Таблица 3. Распределение городского населения Тувинской АССР по полу и возрасту в 1989 г. ${ }^{1}$ Table 3. The age and gender distribution of the urban population of Tuvan ASSR, 1989.

\begin{tabular}{|c|c|c|c|}
\hline Возраст & Оба пола & Мужчины & Женщины \\
\hline $\begin{array}{c}\text { Из общей численности } \\
\text { в возрасте моложе } \\
\text { трудоспособного }\end{array}$ & 46084 чел. & 23129 чел. & 255 чел. \\
\hline $\begin{array}{c}\text { в трудоспособном } \\
\text { возрасте }\end{array}$ & 85893 чел. & 44168 чел. & 425 чел. \\
\hline $\begin{array}{c}\text { в возрасте старше } \\
\text { трудоспособного }\end{array}$ & 13666 чел. & 3838 чел. & 9828 чел. \\
\hline
\end{tabular}

По мнению Е. Е. Тиниковой, в национальных республиках Южной Сибири были схожие причины перехода сельского населения в городские поселения, связанные с развитием промышленности, ростом потребности в рабочей силе в городах и рабочих поселках; механизацией сельского хозяйства; относительной устойчивостью сохранявшихся социальных различий между жителями города и села по характеру труда, по культурно- бытовым условиям (Тиникова, 2018: 244).

Откуда приезжали люди в Туву?

Как видно из данных таблицы 4, структура городского населения формировалась в основном за счет сельских жителей из регионов РСФСР. Количество мигрантов из сел превышало число мигрантов из городов более чем на 1000-3000 чел. в год. Лишь в 1969 г. количество прибывших из городов было на 1040 чел. больше, чем из сельской местности.

Л. В. Гребнев выяснил, что более половины всех приехавших рабочих были выходцами из Красноярского края, причем около $60 \%$ из них были жители сельской местности. Среди приезжих из других районов страны преобладали жители городов, формировавшие ядро наиболее квалифицированных рабочих. Также он констатирует, что в конце семилетки (1959-1965 гг.) в целом по республике в составе рабочих промышленности, транспорта и строительства Кызыла и Чадана преобладало приезжее население (Гребнев, 1967: 78). Так, в 1965 г. на промышленных предприятиях Кызыла работали 46,6\% выходцев из Красноярского края, в Чадане и Ак-Довураке 41\%, 20\% соответственно. Из европейской части СССР больше приезжих специалистов было в промышленности Ак-Довурака - 22,3\%, тогда как в Кызыле и Чадане они составляли $12,8 \%$ и $11,6 \%$. Но в строительной отрасли г. Кызыла $31 \%$ рабочих приехали из европейской части СССР, это было значительно больше, чем в других городах. А вот выходцев из сел Тувы больше всего работало в строительстве г. Ак-Довурака - 66,5\% (там же: 79).

За 1945-1975 гг. число рабочих в промышленности Тувы возросло в 15,8 раза. Особенно значительный рост имел место в электроэнергетике $(20,2$ раза), цветной металлургии $(925,5)$, металлообработке (180) и в промышленности строительных материалов (950). За счет именно этих отраслей, в значительной мере определяющих темпы индустриализации Тувы, и произошли структурные сдвиги в промышленности (Сердобов, 1977: 23).

Первоначально внешняя миграция формировалась исходя из государственных интересов, специалисты направлялись на стройки и на вновь открытые предприятия, выпускники вузов по распределению в сферы образования и здравоохранения. С другой стороны, процесс расселения никогда не являлся полностью управляемой сферой жизни, люди часто самостоятельно срывались с места в поисках работы и лучших мест для жизни.

${ }^{1}$ По данным документа «Итоги Всероссийской переписи населения 1989 г. по Тувинской АССР. Абсолютные данные» (НА РТ, ф. 263, оп. 1, д. 1, л. 59). 
Таблица 4. Таблица по количеству прибывших в города Тувы в 1949-1969 г2. из РСФСР и СССР. Table 4. The new arrivals from RSFSR and USSR to the cities and towns of Tuva, 1949-1969.

\begin{tabular}{|c|c|c|c|c|c|c|c|c|c|c|c|}
\hline \multirow{2}{*}{$N o$} & \multirow{2}{*}{ Год } & \multicolumn{5}{|c|}{ Прибыло из РСФСР } & \multicolumn{5}{|c|}{ Прибыло всего из СССР } \\
\hline & & Из городов & $\begin{array}{l}\text { Из сельской } \\
\text { местности }\end{array}$ & Неизвестно & Всего & $\begin{array}{c}\text { Механический } \\
\text { прирост }\end{array}$ & Из городов & $\begin{array}{l}\text { Из сельской } \\
\text { местности }\end{array}$ & Неизвестно & Всего & $\begin{array}{c}\text { Механический } \\
\text { прирост }\end{array}$ \\
\hline 1 & 1949 & 2155 & 3406 & 208 & 5769 & +864 & - & - & - & - & - \\
\hline 2 & 1951 & 2827 & 4717 & 48 & 7592 & +2638 & 2989 & 4798 & 151 & 7938 & +2670 \\
\hline 3 & 1952 & 2512 & 4418 & 175 & 7105 & +1995 & 2862 & 4519 & 436 & 7817 & +216 \\
\hline 4 & 1953 & 3085 & 6164 & 29 & 9278 & +3312 & - & - & - & - & - \\
\hline 5 & 1955 & - & - & - & - & - & 3937 & 5240 & 595 & 9772 & +1878 \\
\hline 6 & 1957 & 4439 & 5906 & 25 & 10370 & +2130 & 4759 & 6029 & 285 & 11073 & +2388 \\
\hline 7 & 1959 & 3366 & 5968 & 277 & 9611 & +1788 & 3624 & 6102 & 277 & 10003 & +1710 \\
\hline 8 & 1960 & 4408 & 7330 & 22 & 11760 & +2813 & 4642 & 7501 & 302 & 12445 & +2905 \\
\hline 9 & 1963 & 4249 & 5804 & 139 & 10192 & +1683 & 5162 & 5988 & 702 & 11852 & +1851 \\
\hline 10 & 1969 & 5878 & 4838 & 19 & 10735 & +1906 & 6217 & 5018 & 696 & 11931 & +1783 \\
\hline
\end{tabular}

1 Таблица составлена на основе статистических данных Тувинского республиканского управления статистики (НА РТ, ф. 263, оп. 1, дд. 245, л. 183; д. 391, л. 78; $\overrightarrow{+} \quad$ д. 464, л. 4; д. 541, л. 5; д. 684, л. 19; д. 837, л. 7; д. 1088, л. 5; д. 1253, л. 9; д. 1696, л. 53; д. 2665, л. 105.). В таблицу включены данные имеющихся в фондах архива отчетов Тувинского республиканского управления статистики. 
Из 4-х экономических подрайонов Тувы: Центрального, Западного, Восточного и Южного, большая часть промышленных предприятий, входивших в состав Кызыльского промышленного узла, была расположена в городах Кызыле, Туране, Шагонаре, а также в поселках Хову-Аксы и Терлиг-Хая и относилась к Центральному экономическому подрайону (Экономика Тувинской ..., 1973: 165).

Центральный подрайон специализировался на добыче угля, производстве электроэнергии, продукции легкой, пищевой, лесной и деревообрабатывающей промышленности, а также на металлообработке. Формировалась новая специализирующая отрасль - цветная металлургия. Подрайон являлся основной базой производства строительных материалов и стройиндустрии республики (там же: 165).

Западный подрайон являлся вторым по уровню хозяйственного развития подрайоном Тувы, специализировавшимся на добыче асбеста и сельскохозяйственном производстве животноводческого направления. Его основным ядром являлся Ак-Довуракский промышленный узел, в состав которого входят предприятия городов Ак-Довурака, Чадана и поселка городского типа Кызыл-Мажалыка (там же: 168$)$.

Конечно, процесс урбанизации в Туве, вошедшей в состав СССР в 1944 г., шел своими темпами. Для сравнения, доля городского населения в СССР в 1959 г., согласно данным Переписи населения СССР 1959 г. ${ }^{1}$, составляла $48 \%$, в 1979 г. $-62 \%^{2}$, в 1989 г. $-66 \%^{3}$, тогда как в Туве к 1989 г. она достигла $47,1 \%$. Тем не менее для Тувы это были кардинальные изменения в образе жизни тувинцев, прежде кочевых скотоводов, связанные с переходом на оседлость, в основном завершившегося к 1959 г.

По итогам Всесоюзной переписи населения 1989 г. в Туве проживало 309100 тыс. чел. За 1944-1990 гг. численность жителей республики увеличилась в 3 раза. Население городов выросло в 23 раза с 6,4 тыс. до 145,6 тыс. чел., в сельской местности - соответственно с 89 тыс. до 163, 4 тыс. чел. (История Тувы, 2016: 392).

Еще одним признаком урбанизации в республике стал тот факт, что к 1989 г. практически выровнялось количество городских и сельских семей (таблица 4).

Таблица 5. Число семей в Тувинской АССР на 1989 г. ${ }^{4}$

Table 5. The number and size of families in Tuvan ASSR in 1989.

\begin{tabular}{|c|l|c|c|}
\hline \multicolumn{1}{|c|}{ № } & \multicolumn{1}{|c|}{ Числотория } & \multicolumn{1}{c|}{$\begin{array}{c}\text { Средний размер семьи (совместно } \\
\text { проживающих членов семьи) }\end{array}$} \\
\hline 1 & Всего по республике & 70657 & 4,0 \\
\hline 2 & Городские семьи & 35451 & 3,6 \\
\hline 3 & Сельские семьи & 35206 & 4,4 \\
\hline 4 & г. Кызыл & 21076 & 3,4 \\
\hline 5 & г. Ак-Довурак & 3536 & 3,9 \\
\hline 6 & г. Туран & 1599 & 3,3 \\
\hline 7 & г. Чадан & 2299 & 4,3 \\
\hline 8 & г. Шагонар & 2326 & 3,8 \\
\hline 9 & пгт Каа-Хем & 1844 & 3,7 \\
\hline 10 & пгт Кызыл-Мажалык & 1206 & 4,4 \\
\hline 11 & пгт Хову-Аксы & 1565 & 3,5 \\
\hline
\end{tabular}

${ }^{1}$ Уровень образования, национальный состав, возрастная структура и размещение населения СССР по республикам, краям и областям. По данным Всесоюзной переписи населения 1959 г. М. : Госстатиздат, 1960. С. 3. ${ }^{2}$ Численность и состав населения СССР. По данным Всесоюзной переписи населения 1979 года. М. : Финансы и статистика, 1984. С. 6.

${ }^{3}$ Болдырев В.А. Население СССР по данным Всесоюзной переписи населения 1989 г. М. : Изд-во Финансы и статистика, 1990. С. 10.

${ }^{4}$ Таблица составлена по материалам Тувинского республиканского управления статистики (НА РТ, ф. 263, оп. 1 , д. 1, лл. 339-341). 
Причем 59\% городских семей проживали в г. Кызыле. Средний размер сельской семьи составлял 4,4 чел., городской - 3,6 чел. При этом тувинская семья по количеству членов (5 чел.) была несколько больше, чем русская (3,7 чел.), за счет разницы в рождаемости (Очерки социального ..., 1983: 124-125).

В материалах переписи 1989 г. указано, что 679 человек, из них 445 жителей городов республики, владели тувинским языком как вторым языком общения (НА РТ, ф. 263, оп. 1, д. 1, л. 106). В их числе русские - 564 чел., хакасы - 60 чел., а также татары, буряты, украинцы, казахи, киргизы, белорусы, армяне, чуваши, корейцы, алтайцы, грузины, молдаване, латыши, калмыки, мордва, китайцы, поляки, адыгейцы.

\section{Заключение}

Мы видим, что важным фактором появления городских поселений в Туве, как и в целом по стране, стало экономическое развитие республики, основой которого раньше было кочевое скотоводство. Государством были поставлены задачи по переводу кочевого населения на оседлость, по выравниванию социально-экономического и культурного уровня развития Тувы с другими регионами, по созданию многоотраслевого промышленного производства, освоение природных ресурсов, особенно минерального сырья, так, например, появился г. Ак-Довурак. Также рост городского расселения происходил за счет придания некоторым поселениям статусов городских поселений, таким как Туран, Чадан, Шагонар и поселков городского типа Хову-Аксы, Кызыл-Мажалыка и Каа-Хема, в которых также создавались предприятия промышленного производства, энергетики, транспорта и др.

Общий подъем социально-экономического развития республики способствовал улучшению условий жизни, повышению качества медицинского обслуживания, соответственно росту численности населения городов. Как показывает статистика, значительным был рост городского населения, что привело к изменениям в социальной структуре общества, так как государственная политика способствовала интенсификации процесса урбанизации во второй половине XX века.

Основными источниками формирования городского населения явились жители сел Тувы и РСФСР, особенно близлежащих районов Красноярского края. А также относительно высокий по сравнению с другими регионами страны естественный прирост горожан. Быстрыми темпами росло население столицы - г. Кызыла, которое в 1989 г. составляло 27\% от общего числа жителей республики. Имеющаяся на сегодняшний день неравномерность городского расселения населения в Туве сложилась еще в середине XX века и определила современную структуру расселения, основной проблемой которой является продолжающийся переезд сельских жителей в г. Кызыл и на его окраины - пгт Каа-Хем, загородные дачные территории, Вавилинский затон, несмотря на то, что промышленный потенциал г. Кызыла значительно упал вследствие деиндустриализации экономики после 1990-х годов.

Непрекращающийся миграционный поток из районов республики в Кызыл не позволяет наращивать, поддерживать иной потенциал - потенциал села и сельских производителей. На фоне разрушенного промышленного производства и сельского хозяйства нерегулируемый процесс урбанизации, который власть не сумела обернуть вспять, усугубляет социально-экономический кризис в республике.

\section{СПИСОК ЛИТЕРАТУРЫ}

Анайбан, 3. В. (2011) Характеристика этнодемографических процессов Тувы в советский период // Новые исследования Тувы. № 2-3. С. 130-150.

Бегзи, А. Д. (1975) Формирование городского населения Тувинской АССР и изменение его социальной структуры и национальный состав // Ученые записки ТНИИЯЛИ. Вып. XVII. Кызыл : Тувинское книжное издательство. 278 c. С. $62-70$.

Бегзи, А. Д. (2017) Экономика советской Тувы: достижения, проблемы и уроки // Новые исследования Тувы. № 4. C. 94-108. DOI: https://www.doi.org/10.25178/nit.2017.4.5

Бегзи, А. Д. (2019) Основные факторы, этапы и особенности реализации урбанизации в Туве // Региональная экономика: технологии, экономика, экология и инфраструктура: Материалы 3-й Международной научнопрактической конференции, посвященной 25-летию ТувИКОПР Со РАН и 45-летию академической науки в Туве (23-25.10.2019, Кызыл, Россия) / под общ. ред. Г. Ф. Балакиной. Кызыл : ТувИКОПР СО РАН. 520 с. С. 52-59.

Городское население Тувинской АССР. Опыт социологического исследования (1981) / отв. ред. В. И. Бойко. Новосибирск : Наука. 223 с. 
Гребнев, Л. В. (1967) Формирование рабочего класса в Туве // Ученые записки. Выпуск ХІІ. Кызыл : Тувинское книжное издательство. 278 с. С. 69-86.

Гребнев, Л. В. (1968) Изменение социальной структуры в Туве // Ученые записки. Вып. ХІІІ. Кызыл : Тувинское книжное издательство. 356 с. С. 47-77.

История Тувы (2016) : в 3 т. / под общ. ред. Н. М. Моллерова. Новосибирск : Наука. Т. III. 455 с.

На перекрестке времени. Урянхайский край. Тувинская Народная Республика. Тувинская Автономная область. Тувинская автономная Советская Социалистическая Республика (2014) : сборник архивных документов и фотодокументов / отв. ред. Д. У. Чамзо. Новосибирск : Сибирское книжное издательство. 480 с.

Очерки социального развития Тувинской АССР (1983) / отв. ред. В. И Бойко., В. Н. Белошапкина, Г. Ч. Ширшин и др. Новосибирск : Наука. 262 с.

Сердобов, Н. А. (1977) Рабочий класс и социально-экономическое развитие Тувы // Великий Октябрь и проблемы новейшей истории Тувы / отв. ред. Ю. Л. Аранчын. Кызыл : Тувинское книжное издательство. 147 с. С. $17-51$.

Тиникова, Е. Е. (2018) Трансформация городского расселения в национальных республиках Южной Сибири в середине XX - начале XXI века // Новые исследования Тувы. № 4. C. 235-257. DOI: https://www.doi.org/10.25178/ nit.2018.4.13

Харунова, М. М.-Б. (2010) «Паспорт» Тувинской автономной области как исторический источник // Ученые записки. Выпуск XXII. Кызыл : Тываполиграф. 503 с. С. 159-167.

Экономика Тувинской АССР (1973) / ред. коллегия: С. В. Клопов (отв. ред.) [и др.]. Кызыл : Тувинское книжное издательство. 377 с.

Дата поступления: 06.06.2021 г.

\section{REFERENCES}

Anaiban, Z.V. (2011) Kharakteristika etnodemograficheskikh protsessov Tuvy v sovetskii period [A characteristics of ethnodemographic processes in Tuva during the Soviet period]. New Research of Tuva, no. 2-3, pp. 130-150. (In Russ.)

Begzi, A.D. (1975) Formirovanie gorodskogo naseleniia Tuvinskoi ASSR iizmenenie ego sotsial'noi struktury i natsional'nyi sostav [The rise of the urban population of the Tuvan ASSR and changes in its social and ethnic structure]. Uchenye zapiski TNIIIaLI, vol. XVII. Kyzyl, Tuvan book publisher. 278 p. Pp. 62-70. (In Russ.)

Begzi, A. D. (2017) Ekonomika sovetskoi Tuvy: dostizheniia, problemy i uroki [The economy of the Soviet Tuva: achievements, challenges and lessons]. New Research of Tuva, no. 4, pp. 94-108. (In Russ.). DOI: https://doi.org/10.25178/ nit.2017.4.5

Begzi, A. D. (2019) Osnovnye faktory, etapy i osobennosti realizatsii urbanizatsii v Tuve. [The main factors, stages and features of urbanization in Tuva]. In: Regional'naia ekonomika: tekhnologii, ekonomika, ekologiia i infrastruktura [Regional Economy: Technologies, Economic Factors, Ecology and Infrastructure]: Proceedingss of the 3rd International Scientific and Practical Conference dedicated to the 25th anniversary of TuvIKOPR Sb RAS and the 45th anniversary of Academic Science in Tuva (23-25.10.2019, Kyzyl, Russia) / ed. by G. F. Balakina and V. O. Oorzhak. Kyzyl, TuvIKOPR SO RAN. 520 p. Pp. $52-59$. (In Russ.)

Gorodskoe naselenie Tuvinskoi ASSR [Urban population of the Tuvan ASSR] (1981) / ed. by V. I. Boiko. Novosibirsk, Nauka. 224 p. (In Russ.).

Grebnev, L.V. (1967) Formirovanie rabochego klassa v Tuve [The rise of the working class in Tuva]. Uchenye zapiski, vol. XII. Kyzyl, Tuvan book publisher. 278 p. Pp. 69-86. (In Russ.)

Grebnev, L.V. (1968) Izmenenie sotsial'noi struktury v Tuve [Changing the social structure in Tuva]. Uchenye zapiski, vol. XIII. Kyzyl, Tuvan book publisher. 356 p. Pp. 47-77. (In Russ.)

Istoriia Tuvy [The History Of Tuva] (2016): in 3 vols. / ed. by V. A. Lamin. Novosibirsk, Nauka. Vol. 3. 455 p. (In Russ.).

Na perekrestke vremeni [At the crossroads of time] (2014): a collection of archival documents and photo documents / eds.: A. M. Dugar-Surun et al. Novosibirsk, Sibirskoe knizhnoe izdatel'stvo. 480 p. (In Russ.).

Ocherki sotsial'nogo razvitiia Tuvinskoi ASSR [Essays on social development of the Tuvan ASSR] (1983) / ed. by Yu. L. Aranchyn. Novosibirsk, Nauka. 262 p. (In Russ.).

Serdobov, N.A. (1977) Rabochii klass i sotsial'no-ekonomicheskoe razvitie Tuvy [Working class and socio-economic development of Tuva]. In: Velikii oktiabr' i problemy noveishei istorii Tuvy [The Great October and the problems of the modern history of Tuva]. Ed. by Yu. L. Aranchin. Kyzyl, Tuvan book publisher. 147 p. Pp. 17-51. (In Russ.) 
Tinikova, E. E. (2018) Transformatsiia gorodskogo rasseleniia v natsional'nykh respublikakh Iuzhnoi Sibiri v seredine XX - nachale XXI veka [Transformation of urban settlement in the national republics of southern Siberia in the mid-20th to early 21st century]. New Research of Tuva, no. 4, pp. 235-257. (In Russ.). DOI: https://doi.org/10.25178/nit.2018.4.13

Kharunova, M. M.-B. (2010) «Pasport» Tuvinskoi avtonomnoi oblasti kak istoricheskii istochnik [The "Passport" of the Tuva Autonomous Region as a historical source]. In: Uchenye zapiski, vol. XXII. Kyzyl, Tyvapoligraf. 503 p. Pp. $159-167$. (In Russ.).

Ekonomika Tuvinskoi ASSR [The economy of Tuvan ASSR] (1973). Ed. by S. V. Klopov. Kyzyl, Tuvan book publishing house. 378 p. (In Russ.).

Submission date: 06.06.2021. 